http://jmscr.igmpublication.org/home/ ISSN (e)-2347-176x ISSN (p) 2455-0450 crossref DOI: https://dx.doi.org/10.18535/jmscr/v7i9.50

\title{
Socio-demographic variables and markers of immunity in HIV seropositive population of a Northern Indian town
}

\author{
Authors \\ Parvez Anwar Khan ${ }^{1 *}$, Nazish Fatima ${ }^{1}$, Haris Manzoor Khan ${ }^{1}$ \\ ${ }^{1}$ Department of Microbiology, J.N.M.C.H, Aligarh Muslim University, Aligarh, India \\ *Corresponding Author \\ Parvez Anwar Khan
}

Assistant Professor, Department of Microbiology, J.N.M.C.H, Aligarh Muslim University, Aligarh, India

\begin{abstract}
Introduction: As per the India HIV Estimation 2015 report, adult (15-49 years) HIV prevalence in India was estimated at $0.26 \%$. Since the early days of HIV infection and AIDS, it has been recognized that the disease progresses in several stages due to the progression of immunosuppression. The level of immunosuppression is linked directly to the CD4+ T-lymphocyte count.

Materials and Methods: The study group comprised of HIV positive patients. Cases were recruited from the outpatient department, wards, Anti-Retroviral Treatment clinic and ICTC, both ART naïve as well as patients on ART were studied. All patients were evaluated by a predesigned protocol.

Results: A total of 160 HIV positive patients were included in this study. The maximum number of patients both male and female were found in the age group of 20 - 40 years. Majority of the patients (80.6\%) were married. Patients belonging to the rural areas. Heterosexual route of transmission of HIV was ascertained in $119(74.4 \%)$ patients out of 160.Most of the patients included in this study were in advanced stage of disease, $48.7 \%$ of patients had their CD4 count less than 200 and only 8\% had their CD4 count more than 500.

Conclusion: Most of the patients were in young and sexually active age group, $\bullet$ Laborers, farmers and drivers comprised the major occupation of the study group. Heterosexual transmission of HIV infection was the most common route. Most of the patients had low CD4 cell count

Keywords: HIV Positive, Socio-demographic variables, transmission, Cd4 Cell count.
\end{abstract}

\section{Introduction}

Acquired Immune Deficiency syndrome (AIDS) was first recognized in the United States in 1981, when the U.S. Centers for Disease Control and Prevention (CDC) reported the unexplained occurrence of Pneumocystis cariniip neumonia in five previously healthy homosexual men in Los Angeles and of Kaposi's sarcoma in 26 previously healthy homosexual men in New York and Los Angeles. ${ }^{1}$ The first case of human immunodeficiency virus/acquired immunodeficiency syndrome (HIV/AIDS) in India was detected in 1986 in the state of Tamilnadu and since then the spread of HIV/AIDS across the nation has been relentless (E.A. Simoes et al.1987). ${ }^{2}$ Cases have been reported from all states and union territories of India.

As per the India HIV Estimation 2015 report, adult (15-49 years) $\mathrm{H} 1 \mathrm{~V}$ prevalence in India was estimated at $0.26 \%(0.22 \%-0.32 \%)$ in 2015 . In 2015, adult HIV prevalence was estimated at $0.30 \%$ 
among males and at $0.22 \%$ among Females. ${ }^{3}$ The total number of People Living with HIV (PLHIV) in India was estimated at 21.17 lakhs (17.11 lakhs26.49 lakhs) in 2015, Uttar Pradesh had 1.50 lakhs PLHIV. $^{3}$

Since the early days of HIV infection and AIDS, it has been recognized that the disease progresses in several stages due to the progression of immunosuppression. The level of immunosuppression is linked directly to the CD4+ T-lymphocyte count (Goedert JJ. et al.1987, Lang W. et al.1989). The destruction of immune system by the virus results in opportunistic infections as well as an increased risk of autoimmune diseases and malignancy.

Absolute CD4 count, CD4 percentage, quantitative HIV-1 RNA (viral load), absolute lymphocyte counts, Neopterin level and p-24 antigenemia have all been proposed as surrogate markers of immune function. Among these, CD4 counts and quantitative HIV-1 RNA levels are used most commonly. Quantitative HIV-1 RNA is a more reliable surrogate marker for progression to AIDS and death than $\mathrm{CD} 4$ counts. ${ }^{5}$

\section{Material and Methods}

The study group comprised of HIV positive patients, irrespective of their age group. Cases were recruited from the outpatient department, wards, AntiRetroviral Treatment clinic and ICTC (Department of Microbiology), J. N. Medical College and Hospital, A.M.U., Aligarh, both ART naïve as well as patients on ART were studied. All patients were evaluated by a predesigned protocol.

The HIV status of all the patients was confirmed at ICTC, J.N. Medical College and Hospital. The HIV antibody status was assessed by three ERS (ELISA, Rapid, and Simple) tests as recommended by the National AIDS Control Organization (NACO), Ministry of Health and Family Welfare, Government of India.TheCD4 cell counts of all the patients were estimated by Flow-Cytometry using Partec Cy Flow Counter (Germany). Routine lab investigations like $\mathrm{Hb}$, TLC, DLC, ESR, LFT and RFT were also done.

\section{Results}

A total of $160 \mathrm{HIV}$ positive patients were included in this study, the maximum number of patients both male and female were found in the age group of 20 - 40 years $116(72.5 \%)$. The youngest patient was 1 year old while the oldest was of 60 years in our study. Total number of males and females was $93(58.1 \%)$ and $67(41.8)$ respectively. The male to female ratio in this study was 1.38:1. (Table 1)

Table 1: Age and sex distribution of HIV positive patients

\begin{tabular}{|l|c|c|c|}
\hline Age in years & Male & Female & Total (\%) \\
\hline $0-10$ & 06 & 05 & $11(06.9)$ \\
\hline $11-20$ & 06 & 02 & $08(05.0)$ \\
\hline $21-30$ & 29 & 29 & $58(36.3)$ \\
\hline $31-40$ & 36 & 22 & $58(36.3)$ \\
\hline $41-50$ & 11 & 09 & $20(12.5)$ \\
\hline$>50$ & 05 & 00 & $05(03.1)$ \\
\hline Total & $93 \quad(58.1)$ & $67(41.8)$ & 160 \\
\hline
\end{tabular}

Majority of the patients $(80.6 \%)$ were married. Patients belonging to the rural areas were $53.7 \%$ while the rest of them lived in towns and cities. Most of the females were house wives while most of the males were manual laborers $(15.6 \%)$ followed by farmers (15\%) and drivers (11.8\%). $20 \%$ of the patients gave the history of migration away from their homes to earn their livelihood.( Table 2)

Table - 2: Demographic profile of study group

\begin{tabular}{|l|c|c|c|c|}
\hline & & Males & Females & Total (\%) \\
\hline Marital status & Married & 75 & 54 & $129(80.6)$ \\
\cline { 2 - 6 } & Unmarried & 18 & 13 & $31(19.3)$ \\
\hline Social \\
background & Rural & 51 & 35 & $86(53.7)$ \\
\cline { 2 - 6 } Occupation & Urban & 42 & 32 & $74(46.2)$ \\
\cline { 2 - 6 } & Farmer & 21 & 03 & $24(15.0)$ \\
\cline { 2 - 6 } & Driver & 19 & 00 & $19(11.8)$ \\
\cline { 2 - 6 } & Laborer & 23 & 02 & $25(15.6)$ \\
\cline { 2 - 6 } & Business & 18 & 00 & $18(11.2)$ \\
\cline { 2 - 6 } & Housewife & - & 56 & $56(35.0)$ \\
\cline { 2 - 6 } & Army/police & 04 & 00 & $04(02.5)$ \\
\cline { 2 - 6 } & Others & 08 & 06 & $14(08.7)$ \\
\hline
\end{tabular}

In adults, heterosexual mode of transmission was suspected if the patient gave a positive history of having multiple unprotected sexual intercourse with a sex worker or if one of the spouse was HIV positive, heterosexual transmission was considered in the other spouse if he/she was also HIV positive, $119(74.4 \%)$ patients out of 160 fulfilled the above mentioned condition and heterosexual contact was considered to be the mode of transmission of HIV in these patients. History of blood or blood products 
transfusion was present in 13 patients (8.1\%).In 16 patients $(10 \%)$ out of total 160 patients mode of transmission could not be specified. (Figure 1)

Figure -1: Mode of transmission of HIV

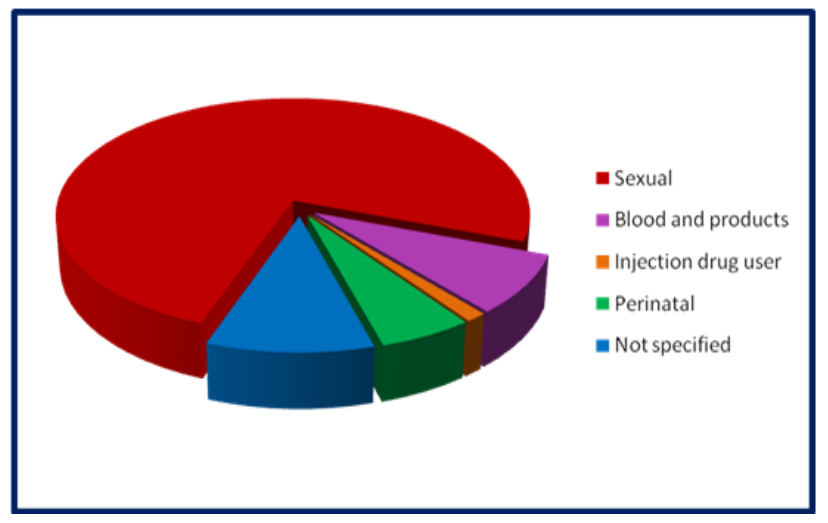

The mean of CD4 count was $246 \pm 171$, out of all the patients $92.5 \%$ had abnormal CD4 count. Total leucocyte count were abnormal in $37.7 \%$ patients. $80 \%$ of the patients had haemoglobin level less than normal. ESR was raised in $56 \%$ of patients. Liver function test comprising of bilirubin, AST, ALT, ALP was deranged in $6.9 \%, 17 \%, 19.3 \%$, and $11 \%$ of the patients respectively. Serum LDH was raised in $13.6 \%$ of patients tested. (Table 3 )

Table-3: Laboratory findings in patients studied

\begin{tabular}{|l|c|c|c|c|}
\hline Investigation & Mean \pm SD & Range & Unit & $\begin{array}{c}\text { Abnormality } \\
(\%)\end{array}$ \\
\hline $\begin{array}{l}\text { CD4+ cell } \\
\text { count }\end{array}$ & $249 \pm 171$ & $22-1135$ & cells/ $\mu \mathrm{l}$ & 92.5 \\
\hline TLC & $7.5 \pm 2.8$ & $\begin{array}{c}0.7- \\
15.3\end{array}$ & $\begin{array}{c}\times \\
10^{3} / \mu \mathrm{l}\end{array}$ & 37.7 \\
\hline Haemoglobin & $8.7 \pm 2.7$ & $\begin{array}{c}3.1- \\
16.1\end{array}$ & $\mathrm{~g} / \mathrm{dL}$ & 80.5 \\
\hline ESR & $35 \pm 18$ & $11-54$ & $\mathrm{~mm} / \mathrm{hr}$ & 56.2 \\
\hline $\begin{array}{l}\text { Bilirubin } \\
\text { Total }\end{array}$ & $1.08 \pm 0.8$ & $0.2-5.6$ & $\mathrm{mg} / \mathrm{dL}$ & 6.9 \\
\hline AST & $32 \pm 12$ & $2-90$ & $\mathrm{IU} / \mathrm{L}$ & 17 \\
\hline ALT & $33 \pm 14$ & $2-92$ & $\mathrm{IU} / \mathrm{L}$ & 19.3 \\
\hline ALP & $42 \pm 19$ & $27-356$ & $\mathrm{IU} / \mathrm{L}$ & 11.1 \\
\hline LDH & $179.6 \pm 59$ & $82-453$ & $\mathrm{IU} / \mathrm{L}$ & 13.6 \\
\hline
\end{tabular}

The patients were also studied according to their CD4 counts as per CDC classification of CD4 T lymphocyte categories.78 (48.7\%) of the patients were in advanced stage of HIV/AIDS and had their CD4 count less than 200 while 69( 43.1\%) patients had CD4 between 200-500 . Only 13(8\%) patients had CD4 more than 500 in this study.(Figure 2)
Figure 2

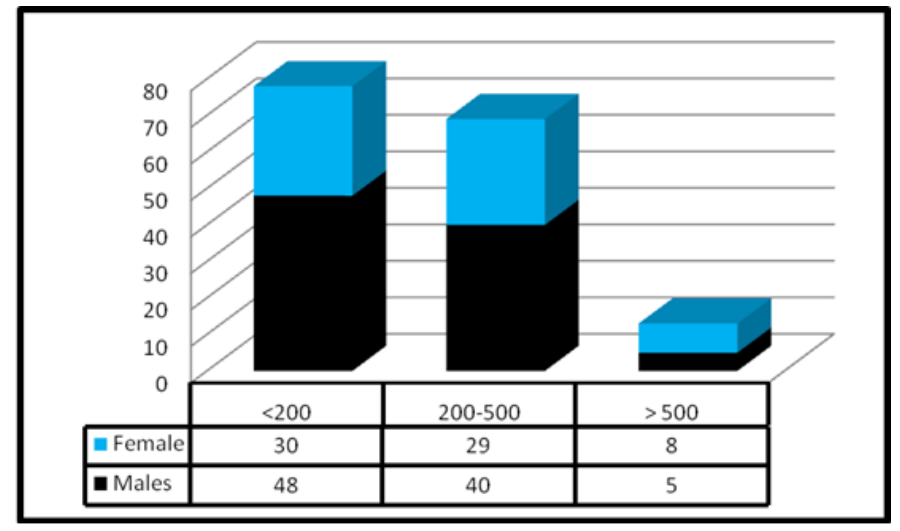

\section{Discussion}

With the mean age of 31.5 years, $72.5 \%$ of patients of this study were in the age group of 21 to 40 years, this section of the population is more affected because they are sexually more active and the social structure is patriarchal. Unfortunately, these patients also happen to be in the economically most productive years of their lives. Morbidity and mortality in this age group causes a huge loss to their household and collectively to the Nation. These findings are consistent with the demographic data given by the National AIDS Control Organization (NACO) which reported mean age of 34 years, ${ }^{3}$ and also with studies elsewhere in India. ${ }^{6,}$ 7,8

The Male: Female ratio in this study was $1.38: 1$, while the males belonged to the wider age spectrum; the females were a considerably younger population. Ratio of female was higher as compared to other Indian studies Anupriya Wadhwa et al. ${ }^{8}$ found the male female ratio of $4.8: 1$ whille SK Sharma et al. ${ }^{9}$ reported the male female ratio of 4.9:1.

$53.7 \%$ of the patients were from rural area as large portion of Indian population still resides in villages and also many of them had history of migration to high risk areas, this confirms the fact that life away from wife and family breeds promiscuity. ${ }^{6}$

Sexual transmission was seen in $75.3 \%$ of patients. 119 patients were heterosexual while one patient was found to be bisexual. All the patients of suspected heterosexual route of transmission gave a history of multiple unprotected intercourses with regular sex workers. Sole homosexual contact was seen in none of the patients. There is some 
difference between these finding and national which reports heterosexual route of transmission in $87 \%$ of cases (Annual Report, NACO, 2016-17) ${ }^{3}$. M. Vajpayee et al. ${ }^{10}$ reported heterosexual route of transmission in $59.8 \%$ cases.

Most of the patients included in this study were in advanced stage of disease, $48.7 \%$ of patients had their CD4 count less than 200 and only $8 \%$ had their CD4 count more than 500 .

\section{Conclusion}

A total of 160 patients were studied. There were $72.5 \%$ of patients in the age group of 21 to 40 years. The Male: Female ratio in this study was 1.38:1, maximum number of patients both male and female were found in the age group of 20 - 40 years. Laborers, farmers and drivers comprised the major occupation of the study group.53.7\% of the cases were from rural areas while $46.2 \%$ was urban population. Heterosexual transmission of HIV infection was the most common route of HIV transmission. Most of the patients included in this study were in advanced stage of disease, $48.7 \%$ of patients had their CD4 count less than 200 and only $8 \%$ had their CD4 count more than 500.

\section{References}

1. Morbidity and Mortality Weekly Report (MMWR) Recommendations and Reports April 10, 2009 / Vol. 58 / No. RR-4.

2. E.A. Simoes, P.G. Babu, T.J. John et al. Evidence for HTLVIII infection in prostitutes in Tamil Nadu (India). Indian J MedRes. 1987; 335-338.

3. National AIDS Control organization. Annual Report, 2016-17. Available at http://naco.gov.in/sites/default/files/NACO \%20ANNUAL\%20REPORT\%20201617.pdf. Accessed 9 June 2019.

4. Goedert JJ, Biggar RJ, Melbye M, Mann DL, Wilson S, Gail MH.et al. Effect of T4 count and cofactors on the incidence of AIDS in homosexual men infected with human immunodeficiency virus. JAMA. 1987; 257:331-4.
5. Mellors JW, Rinaldo CR, Gupta P, White RM, Todd JA, Kingsley LA. Prognosis in HIV-1 infection predicted by the quantity of thevirus in plasma. Science. 1996;272:116770.

6. Kothari K \& Goyal, S. (2001). Clinical profile of AIDS. J Assoc Physicians India 49, 435-438.

7. Kumarasamy N, Solomon S, Flanigan TP, Hemalatha R, Thyagarajan SP, Mayer KH: Natural history of Human immunodeficiency virus disease in southern India. Clin Infect Dis 2003, 36:79-85.

8. Anupriya Wadhwa, Ravinder Kaur, Satish Kumar Agarwal, Shyama Jain and Preena Bhalla: AIDS-related opportunistic mycoses seen in a tertiary care hospital in North India; Journal of Medical Microbiology 2007; 56: 1101-1106.

9. Sharma SK, Aggarwal G, Seth P, Saha PK: Increasing HIV seropositivity among adult tuberculosis patients in Delhi. Indian J MedRes 2003, 117:239-242.

10. M. Vajpayee, S Kanswal, P Seth, N Wig , Spectrum of Opportunistic Infections and Profile of CD4+ Counts among AIDS Patients in North India, Infection 2003; 31: 336-340. 